\title{
Insecticide Activity of Lectins and Secondary Metabolites
}

\author{
Patrícia M.G. Paiva', Thiago H. Napoleão ${ }^{1}$, \\ Roberto A. Sá ${ }^{2}$ and Luana C.B.B. Coelho ${ }^{1}$ \\ ${ }^{1}$ Departamento de Bioquímica, Centro de Ciências Biológicas, Universidade Federal de \\ Pernambuco, Av. Prof. Moraes Rego, S/N, 50670-420, Recife-PE, \\ ${ }^{2}$ Centro Acadêmico do Agreste, Universidade Federal de Pernambuco, 55002-970, \\ Caruaru-PE, \\ Brazil
}

\section{Introduction}

Proteins are polymers of amino acids (molecules containing an amino group, a carboxylic group and a hydrophobic or hydrophilic side chain) present in all organisms. Apolar, polar uncharged and electrically charged amino acids are covalently linked through peptide bonds (amide bonds) and the sequence they form in the polypeptide chain (primary structure) determines the tertiary or quaternary structures ultimately presenting some biological activity. Proteins can be formed by one or multiple polypeptides (subunits) with or without a non-amino acid molecule (carbohydrate, ion, lipid, etc) linked to them.

Lectins comprise a heterogeneous group of non-immune proteins that interact with carbohydrates. This interaction is behind a number of biological properties, including antimicrobial, antitumoral, hemagglutinating, mitogenic and insecticide activities.

The specificity of the carbohydrate binding site is determined by the amino acids forming the lectin molecule, as well as shape and the spatial arrangement of neighboring amino acids; additionally, metal ions may contribute for correct positioning of the amino acid residues for binding to the carbohydrate (Sharon and Lis, 2001). Lectins can be divided into those that bind monosaccharides as well as oligosaccharides, and those that recognize only oligosaccharides (Sharon and Lis, 2007). Depending on carbohydrate specificity, they can be classified as: glucose/mannose, $\mathrm{N}$-acetylglucosamine, galactose, $\mathrm{N}$-acetylgalactosamine, fucose and sialic acid-binding lectins (Wu et al., 2001). The hemagglutinating activity assay (Figure 1A) in presence of free carbohydrates (Figure 1B) has been proved to be a useful tool to characterize lectin specificity.

Plant lectins have been isolated from bark, cladodes, flowers, leaves, rhizomes, roots and seeds. They differ from each other with respect to their molecular structures, carbohydratebinding specificities, and biological activities. The compact globular structures, molecular aggregation and glycosylation of lectins in general result in high structural stability (Kawsar et al., 2008; Moreno et al., 2008).

In general, lectin isolation procedures include protein extraction steps with aqueous solvent, the production of a lectin-rich fraction, and separation of lectin from protein or non-protein 
contaminants by chromatography. Lectin solubility and stability vary with the sequence of amino acids in the polypeptide chain, and such structural features can be exploited to provide concentrated lectin preparations. Lectins can be precipitated from extracts by adding ammonium sulfate at high concentration (salting out method) or organic solvents (Santana et al., 2008; Napoleão et al., 2011). Heat-stable lectins can be partially purified by submitting the extract to high temperature for removal of other proteins (Santana et al., 2008). Lectins are purified by ion exchange, molecular exclusion and/or affinity chromatography that rely on characteristics like charge, size and biological affinity of lectin for solid phases, respectively.

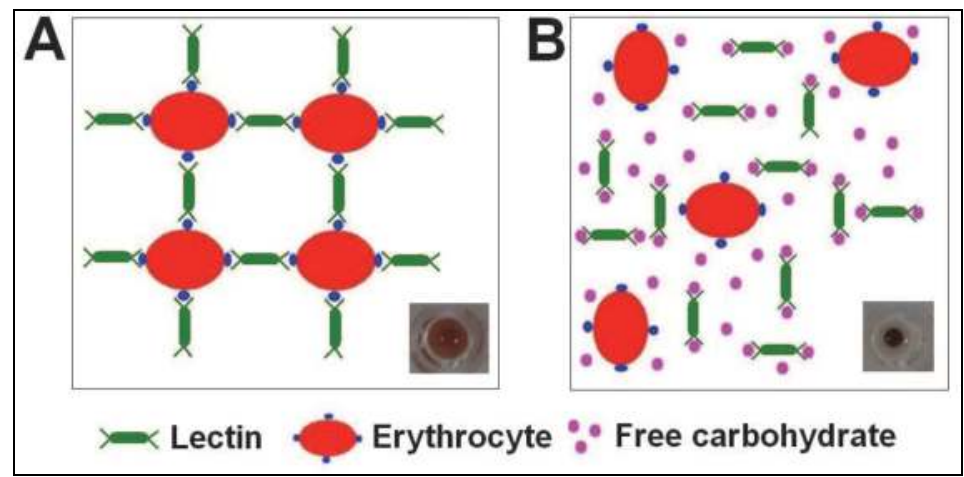

Fig. 1. Schematic representation of erythrocyte network promoted by lectin binding to surface carbohydrates (A) and inhibition of hemagglutinating activity by free carbohydrate (B). Aspects of assays in microtiter plates (insets).

Isolated lectin can be detected by polyacrylamide gel electrophoresis (PAGE) using dyes such as Coomassie Brilliant Blue or Amido black (Reisfeld et al., 1962; Laemmli, 1970). Specific staining techniques with Schiff's reagent (Pharmacia Fine Chemicals, 1980) or Concanavalin A-Peroxidase (Hinata and Nishio, 1981) can easily reveal the presence of glycan; carbohydrate moiety characterization can be performed after lectin tryptic digestion in gel followed by enzymatic deglycosylation and mass spectrometric analysis (Nasi et al., 2009).

\subsection{Lectins from Bauhinia monandra leaf and secondary roots}

Bauhinia monandra (Angiosperms, Eudicots, Rosids, Eurosids I/Fabidae, Order Fabales, Family Fabaceae) has the popular names "pata-de-vaca" in Portuguese, "orquidea del pobre" in Spanish, and pulse or Napoleon's plume in English (Judd et al., 2007; Souza et al., 2011b). B. monandra leaf infusions are used as medicine in the treatment of diabetes mellitus.

Two lectins were purified at milligram level from leaf and secondary roots of B. monandra, and were called BmoLL and BmoRoL, respectively. The isolation procedures included protein extraction with $0.15 \mathrm{M} \mathrm{NaCl}$, ammonium sulphate $(60 \%)$ fractionation and affinity chromatography on guar gel column (Coelho and Silva, 2000; Souza et al., 2011b).

BmoLL agglutinated rabbit and human (AB and $B$ types) erythrocytes and this hemagglutinating activity was inhibited by $\mathrm{D}(+)$ galactose and $\mathrm{D}(+)$ rafinose. It was detected over a broad $\mathrm{pH}$ range, being heat stable up to $50{ }^{\circ} \mathrm{C}$ (Coelho and Silva, 2000). 
Polyacrylamide gel electrophoresis for denatured proteins (SDS-PAGE) revealed that BmoLL is formed by two polypeptides (a $26-\mathrm{kDa}$ subunit and a $33-\mathrm{kDa}$ glycosylated subunit). This lectin did not induce genotoxic effects in a series of cell-free and bacterial assays (Sisenando et al., 2009).

BmoRoL showed hemagglutinating activity on human and rabbit erythrocytes at a $\mathrm{pH}$ range of 6.5 to 7.5, and was active up to $60^{\circ} \mathrm{C}$, losing its activity above this temperature. SDSPAGE revealed that the lectin was a $26-\mathrm{kDa}$ glycoprotein. BmoRoL showed antifungal activity against Fusarium solani and F. oxysporum (Souza et al., 2011b).

\subsection{Lectin from Opuntia ficus indica cladodes}

Opuntia ficus indica Mill. (Angiosperms, Eudicots, Order Caryophyllales, Family Cactaceae) has the popular names "palma forrageira" or "figo-da-Índia" in Portuguese, "nopal" or "tuna" in Spanish, and Indian fig opuntia or barbary fig in English (Judd et al., 2007). Cladodes are used in folk medicine and studies demonstrated their diuretic, antiulcer and wound-healing activities (Galati et al., 2001; Galati et al., 2002; Trombetta et al., 2006). O. ficus indica is grown in northeastern Brazil as an important feed source for animals, and cladodes have been reported to be a component in sheep feed (Tegegne et al., 2007).

The procedure for isolation of $O$. ficus indica lectin (OfiL) included protein extraction with $0.15 \mathrm{M} \mathrm{NaCl}$ and chromatography of extract on a chitin column. OfiL agglutinated rabbit, chicken or human erythrocytes. The hemagglutinating activity was inhibited by monosaccharides and glycoproteins, stimulated by $\mathrm{Ca}^{2+}$ or $\mathrm{Mg}^{2+}$, remaining stable across wide $\mathrm{pH}$ and temperature ranges. SDS-PAGE revealed that lectin is a single $8.4-\mathrm{kDa}$ polypeptide. OfiL showed antifungal activity against Colletotrichum gloeosporioides, Candida albicans, Fusarium decemcellulare, Fusarium lateritium, Fusarium moniliforme, Fusarium oxysporum and Fusarium solani. This lectin was mainly active on C. albicans (Santana et al., 2009).

\subsection{Lectins from Moringa oleifera seeds}

Moringa oleifera (Angiosperms, Eudicots, Rosids, Eurosids II/Malvidae, Order Brassicales, Family Moringaceae) has the popular names "moringa" in Portuguese, "árbol del ben" in Spanish, and horseradish tree in English (Judd et al., 2007). The seeds are widely used in developing countries as a natural coagulant to treat water for human consumption. It has been demonstrated that a $3-\mathrm{kDa}$ organic polyelectrolyte and proteins with molecular mass of 6.5 to $13 \mathrm{kDa}$ and isoelectric points between 9.6 and 11.0 have coagulant properties (Gassenschmidt et al., 1995; Ndabigengesere et al., 1995; Okuda et al., 2001; Ghebremichael et al., 2005).

Santos et al. (2005) revealed the presence of water-soluble M. oleifera lectin (WSMoL) in M. oleifera seed extracts by detection of hemmaglutinating activity. The procedure for WSMoL isolation was defined by Coelho et al. (2009) and included the steps of protein extraction with water, precipitation of lectin with ammonium sulfate (60\% saturation) and chromatography of precipitated fraction on a chitin column. WSMoL agglutinated human and rabbit erythrocytes in a broad $\mathrm{pH}$ range of 4.5 to 9.5 and when kept at $100{ }^{\circ} \mathrm{C}$ for $5 \mathrm{~h}$ plus incubation overnight at $37^{\circ} \mathrm{C}$. The carbohydrate binding site of lectin recognized $\mathrm{D}(+)-$ fructose and $\mathrm{N}$-acetylglucosamine, since these monosaccharides inhibited the hemagglutinating activity (Rolim et al., 2011). MALDI-TOF/TOF analysis revealed that WSMoL showed similarity with M. oleifera protein (Coelho et al., 2009). Genotoxicity assessment of WSMoL using the cell-free plasmid DNA as well as the Ames and Kado 
assays showed that this lectin was nonmutagenic (Rolim et al., 2011). WSMoL showed coagulant and antibacterial activities against Escherichia coli, Staphylococcus aureus and natural lake water bacteria (Ferreira et al., 2011).

The procedure for isolation of coagulant M. oleifera lectin (cMoL) was defined by Santos et al. (2009) and included the steps of protein extraction with $0.15 \mathrm{M} \mathrm{NaCl}$, precipitation of lectin with $60 \%$ ammonium sulfate and chromatography of precipitated fraction on guar gel column. cMoL agglutinated human and rabbit erythrocytes in a broad $\mathrm{pH}$ range of 4.0 to 9.0 and when kept at $100{ }^{\circ} \mathrm{C}$ for $7 \mathrm{~h}$. The hemagglutinating activity of $\mathrm{cMoL}$ was inhibited by several carbohydrates, but not by $\mathrm{D}(+)$-fructose. SDS-PAGE revealed that $\mathrm{cMoL}$ had a main 26.5-kDa polypeptide band. cMoL showed coagulant property and the ability to bind humic acid, which is interesting when the aim is to remove humic acids from water (Santos et al., 2009; Santos et al., 2011a; Santos et al., 2011b).

\subsection{Lectins from Myracrodruon urundeuva bark, heartwood and leaf}

Myracrodruon urundeuva (Angiosperms, Eudicots, Rosids, Eurosids II/Malvidae, Order Sapindales, Family Anacardiaceae) has the popular names "urundel" in Spanish, pepper tree in English and "aroeira do sertão" in portuguese (Leite, 2002; Judd et al., 2007). The plant has great importance in traditional medicine. Aqueous extracts of the bark showed anti-ulcer and anticholinergic, inflammatory, antidiarrhoeal and analgesic activities (Rao et al., 1987; Almeida-Cortez et al., 2007). M. urundeuva heartwood is excellent for poles, fences, pillars, beams, frames, bridges, mills, rafters, parquet, flooring, roofing and turned parts (Mainieri and Chimelo, 1989). Paes et al. (2002) showed that M. urundeuva heartwood was resistant to fungi (Postia placenta and Neolentinus lepideus) and termite (Nasutitermes corniger). M. urundeuva bark, heartwood and leaf are sources of lectins called MuBL, MuHL and MuLL, respectively. The procedures for isolation of these lectins included protein extraction by $0.15 \mathrm{M} \mathrm{NaCl}$, precipitation of lectins with ammonium sulphate (at different saturations for each lectin) and chromatography on a chitin column. The three lectins agglutinated human and rabbit erythrocytes in a broad $\mathrm{pH}$ range, and the hemagglutinating activities were inhibited by $\mathrm{N}$-acetylglucosamine. SDS-PAGE revealed that MuBL, MuHL and MuLL are polypeptides of 14, 14.4 and $14.2 \mathrm{kDa}$, respectively (Sá et al., 2009c; Napoleão et al., 2011). MuHL showed antimicrobial activity inhibiting the growth of numerous bacteria (Bacillus subtilis, Corynebacterium callunae, Escherichia coli, Klebsiella pneumoniae, Pseudomonas aeruginosa, Staphylococcus aureus and Streptococcus faecalis) and fungi (Fusarium oxysporum, F. decemcellulare, F. fusarioides, F. solani and F. verticilioides (Sá et al., 2009b).

\section{Insecticidal activity of lectins}

Lectins have deleterious effects against larvae, developing stages and mature forms of insects from orders Coleoptera, Diptera, Hemiptera, Homoptera, Hymenoptera, Isoptera, Lepidoptera and Neuroptera (Murdock et al., 1990; Eisemann et al., 1994; Powell et al., 1995; Zhu-Salzman et al., 1998; Bandyopadhyay et al., 2001; Isidro et al., 2001; Hogervorst et al., 2006; Kaur et al., 2006; Coelho et al., 2007; Macedo et al., 2007; Fitches et al., 2008; Sá et al., 2008; Coelho et al., 2009; Sá et al., 2009c; Silva et al., 2009; Napoleão et al., 2011; Oliveira et al., 2011; Souza et al., 2011b). Insecticide activity of lectin is generally evaluated by bioassays that incorporate the lectin into artificial diets offered to insects, with insects dying from nutritional deprivation. It has been shown that lectins are resistant to proteases present in the insect gut, a property responsible for their active presence in the digestive tract, 
eventually with insecticide effects (Macedo et al., 2007; Napoleão et al., 2011; Oliveira et al., 2011).

The precise mechanisms of insecticidal action of lectins remain unknown, though it has been suggested that this entomotoxic activity seems to depend upon the carbohydrate recognition property they exhibit. Plant lectins with affinity for $\mathrm{N}$-acetylglucosamine and chitin-binding property are able to bind chitin and glycosylated proteins of the peritrophic matrix, interfering in the digestion and absorption of nutrients (Tellam et al., 1999; Peumans and Van Damme, 1995; Zhu-Salzman et al., 1998; Zhu-Salzman and Salzman, 2001; Carlini and Grossi-de-Sá, 2002; Macedo et al., 2004; Macedo et al., 2007). The peritrophic matrix constitutes a membrane found in the midgut that separates the contents of the gut lumen from the digestive epithelial cells. The matrix contains a network composed by chitin (polymer of $\mathrm{N}$-acetylglucosamine) and glycoproteins such as peritrophins. The importance of the integrity of the peritrophic matrix lies in the protection it offers to midgut epithelial cells against microorganism infection and mechanical damage by abrasive food particles, as apart from the compartmentalization of digestive processes (Hegedus et al., 2009).

Ultrastructural studies have shown abnormalities caused by Triticum vulgaris lectin in midgut of Ostrinia nubilalis and Drosophila such as hypersecretion of many disorganized layers of peritrophic matrix and morphological changes of microvilli (Harper et al., 1998; Li et al., 2009; Vandenborre et al., 2011). Lectin may also cross the midgut epithelial barrier by transcytosis, entering the insect circulatory system and resulting in a toxic action against endogenous lectins involved in haemolymph self-defense mechanisms (Fitches et al., 2001). Lectin may be internalized by endocytotic vesicles into the epithelial cells, blocking nuclear localization and nuclear sequence-dependent protein import, thus inhibiting cell proliferation (Yu et al., 1999).

\subsection{Larvicidal activity of lectins against Callosobruchus maculatus and Zabrotes subfasciatus}

Bruchid beetles (Family Chrysomelidae, Subfamily Bruchinae) are small insects under $1 \mathrm{~cm}$ in size mainly known for the damage they cause to leguminous seeds. Callosobruchus is a cosmopolitan genus behind lowered seed weight, germination viability and marketability, since eggs are laid attached to beans; larvae and pupae develop inside the seeds, which can be attacked both in the field and in storage (Edvardsson and Tregenza, 2005; Souza et al., 2011a). C. maculatus (cowpea weevil) is among the main pests of stored cowpea, Vigna unguiculata (Angus et al., 2011). Synthetic chemicals, grain protectants and fumigants are extensively used to control insect pests in stored grains; however, the usage of chemical insecticides leads to insecticide residues in grains, and has promoted the emergence of selected resistant populations (Loganathan et al., 2011).

Another important species of bruchid beetles is Zabrotes subfasciatus (Mexican bean weevil), which is native to Central and South America. It is one of the main pests of stored beans (Phaseolus vulgaris) in Brazil. The females of Z. subfasciatus are able to oviposit on the seeds after dehiscence or even when they are already inside the pods, which they enter through perforations (Credland and Dendy, 1992; Sari et al., 2003).

BmoLL showed deleterious effects against C. maculatus and Z. subfasciatus larvae (Table 1). An artificial seed containing $0.32 \%$ BmoLL promoted $50 \%$ mortality of C. maculatus larvae, while a $50 \%$ mass decrease was detected in larvae reared on a diet with seeds containing $0.4 \%$ BmoLL. Considering Z. subfasciatus, $50 \%$ mortality and $20 \%$ mass decrease were detected when larvae fed on artificial seeds containing 0.5\% BmoLL (Macedo et al., 2007). 
Additional assays revealed the ability of BmoLL to bind to a chitin column, the resistance of lectin to digestion by enzymes from C. maculatus and Z. subfasciatus larvae, the ability of BmoLL-Sepharose column to bind to proteins from midgut homogenates, and the inhibition of a-amylase activity from midgut by BmoLL. Based on these data, it was suggested that the larvicidal activity may be due to BmoLL binding to chitin from gut structures, cell surface glycosylated receptor or sugar moiety of glycoproteins, resistance of lectin to proteolysis by midgut enzymes, and a damaging effect on the digestive enzyme activity (Macedo et al., 2007).

\begin{tabular}{|c|c|c|}
\hline $\begin{array}{l}\text { Lectin source and } \\
\text { abbreviation }\end{array}$ & Insect & Damage \\
\hline $\begin{array}{l}\text { Bauhinia monandra leaf } \\
\text { (BmoLL) }\end{array}$ & $\begin{array}{c}\text { Callosobruchus maculatus } \\
\text { Zabrotes subfasciatus } \\
\text { Ephestia kuehniella }\end{array}$ & $\begin{array}{l}\text { Mortality of larvae; decreased larval } \\
\text { weight; decreased a-amylase activity. } \\
\text { Mortality of larvae; decreased larval } \\
\text { weight. } \\
\text { Decreased larval weight. }\end{array}$ \\
\hline $\begin{array}{l}\text { B. monandra secondary } \\
\text { roots (BmoRoL) }\end{array}$ & Nasutitermes corniger & $\begin{array}{l}\text { Mortality of workers and soldiers } \\
\text { after ingestion. }\end{array}$ \\
\hline $\begin{array}{l}\text { Opuntia ficus indica } \\
\text { cladodes (OfiL) }\end{array}$ & N. corniger & $\begin{array}{l}\text { Mortality of workers and soldiers } \\
\text { after ingestion. }\end{array}$ \\
\hline $\begin{array}{c}\text { Moringa oleifera seeds } \\
\text { WSMoL }\end{array}$ & Aedes aegypti & $\begin{array}{l}\text { Mortality of fourth-stage larvae }\left(\mathrm{L}_{4}\right) \\
\text { increased gut volume; disruption of } \\
\text { gut underlying epithelium }\end{array}$ \\
\hline \multirow{3}{*}{ cMoL } & N. corniger & $\begin{array}{l}\text { Mortality of workers and soldiers } \\
\text { after ingestion. }\end{array}$ \\
\hline & E. kuehniella & $\begin{array}{l}\text { Decreased larval weight; delayed } \\
\text { development; mortality of pupae; } \\
\text { decreased adult emergence. }\end{array}$ \\
\hline & N. corniger & Mortality of workers after ingestion. \\
\hline $\begin{array}{l}\text { Myracrodruon urundeuva } \\
\text { Bark and heartwood } \\
\text { (MuBL and MuHL) }\end{array}$ & A. aegypti & Mortality of $\mathrm{L}_{4}$ \\
\hline $\begin{array}{l}\text { MuBL, MuHL and leaf } \\
\text { lectin (MuLL) }\end{array}$ & N. corniger & $\begin{array}{l}\text { Mortality of workers and soldiers } \\
\text { after ingestion; bacteriostatic and } \\
\text { bactericide effect against gut } \\
\text { symbionts. }\end{array}$ \\
\hline
\end{tabular}

References: Macedo et al. (2007); Sá et al. (2008); Sá et al. (2009c); Coelho et al. (2009); Napoleão et al. (2011); Oliveira et al. (2011); Paiva et al. (2011); Souza et al. (2011b).

Table 1. Insecticidal activity of lectins. 


\subsection{Larvicidal and pupicidal activities of lectins against Ephestia (Anagasta) kuehniella}

Ephestia kuehniella (many times referred to as Anagasta kuehniella, currently being Anagasta, ranked as a subgenus of Euphestia) is a moth belonging to the Pyralidae family, and today is a worldwide pest of stored grains, nuts, and legumes. It is commonly found in flour mills. Popularly known as flour moth, E. kuehniella also feeds on wheat flour, corn meal, seeds, dried fruits, pasta, baked goods, cocoa, and other stored foods (Gallo et al., 2002; Macedo et al., 2003; Tounsi et al., 2005). Its life cycle lasts 3-4 months and comprises egg, larvae, pupa and adult stages. The larvae (caterpillars) infest the stored product and are the most damaging stage. They produce silk building webs and cocoons in which they complete their development. Next, pupation occurs in the same site. The adults live approximately 14 days and do not feed (Bennett, 2003).

The effect of BmoLL against E. kuehniella was determined in a study using an artificial diet containing lectin concentrations of $0.25 \%, 0.5 \%$ or $1.0 \%$. The moths were fed and the mass and number of neonate larvae (fourth instar) were determined (Macedo et al., 2007). The data showed that BmoLL up to $1 \%$ did not decrease the survival of larvae, though it produced a $40 \%$ weight decrease (Table 1). The authors reckoned that for every $1 \%$ point increase in BmoLL dose, mass decreased by $0.61 \mathrm{mg}$. BmoLL was resistant to hydrolysis by E. kuehniella midgut extracts for $48 \mathrm{~h}$.

The evaluation of insecticidal action of cMoL against E. kuehniella used neonate first instar larvae and artificial diet containing $0.5 \%, 1.0 \%$ or $2.0 \%$ cMoL. The effect of lectin was determined based on the parameters: weight and number of fourth instar larvae, weight of pupae, time at which the adults emerged and number of adults that emerged (Oliveira et al., 2011). cMoL reduced larval weight, delayed the larval development time by 15 days, promoted pupal mortality and produced low rates of adult emergence, though it did not interfere in larval survival (Table 1). The same study also reported the resistance of cMoL to proteolysis by E. kuehniella midgut enzymes.

\subsection{Termiticidal activity of lectins against Nasutitermes corniger}

The tropicopolitan genus Nasutitermes (Termitidae family) includes arboreal wood-feeding termites that build their nests in roofs, linings, and structural spans as well as on the soil or above its level (Edwards and Mill, 1986; Scheffrahn et al., 2002). Soldiers of all Nasutitermes are easily identified by the dark-brown color of their heads and the characteristically conical nasus that emits a defensive secretion, as well as the presence of six erect setae projecting from the vertex (Scheffrahn et al., 2002). One of the most dominant and broadly distributed species is $N$. corniger. These termites are able to invade the urban environment, attacking wood in the structures of buildings (Scheffrahn et al., 2005; Paes et al., 2007).

Termiticidal activity of lectins (Table 1 ) has been evaluated by a no-choice bioassay (Figure 2). Briefly, a filter paper disk impregnated with lectin solution or $0.15 \mathrm{M} \mathrm{NaCl}$ (negative control) is placed in petri plates. Workers and soldiers are transferred to each plate and the rate of insect survival is determined daily, upon the death of all insects.

The first report of toxic effect of a lectin against termites was the insecticidal activity of MuHL against $N$. corniger. When concentrations of $0.1,0.2,0.4$ and $0.8 \mathrm{mg} \mathrm{ml}^{-1}$ of this lectin were used, it promoted mortality of termites with $\mathrm{LC}_{50}$ values of $0.248 \mathrm{mg} \mathrm{ml}^{-1}$ for workers and $0.199 \mathrm{mg} \mathrm{ml}^{-1}$ for soldiers (Sá et al., 2008). That study suggested that resistance of the heartwood to termite attack may be linked to termiticidal activity of MuHL. The termiticidal effect of lectins isolated from M. urundeuva bark and leaf (Table 1) was determined by 
Napoleão et al. (2011). Both MuBL and MuLL killed workers (LC $\mathrm{L}_{50}$ of 0.974 and $0.374 \mathrm{mg} \mathrm{ml}^{-}$ 1 , respectively) and soldiers ( $\mathrm{LC}_{50}$ of 0.787 and $0.432 \mathrm{mg} \mathrm{ml}^{-1}$, respectively).

Despite having the common property of binding to chitin, the lectins of M. urundeuva differently affected the survival of $N$. corniger. MuBL was less active against both castes than the other two lectins, and MuHL was more termiticidal against workers than. It has been reported that insecticidal activity of MuBL and MuLL can be due to the resistance of $M$. urundeuva lectins to proteolysis by enzymes from $N$. corniger gut, and to antibacterial action against symbiotic gut bacteria that is essential for termite survival (Napoleão et al., 2011).

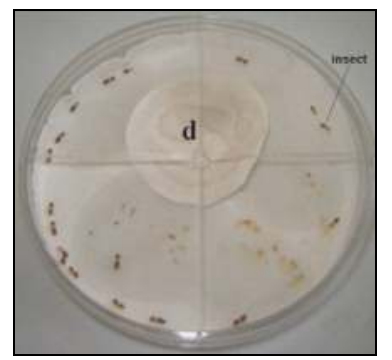

Fig. 2. Aspects of no-choice termiticidal assay used to evaluate insecticidal activity of lectins. The disk (d) of filter paper is impregnated with lectin solution.

The lectin from B. monandra secondary roots (BmoRoL) at concentrations of $0.025,0.05,0.1$, 0.2 and $0.4 \mathrm{mg} \mathrm{ml}^{-1}$ also induced the mortality of $N$. corniger (Souza et al., 2011b). This lectin was more efficient against soldiers ( $\left.\mathrm{LC}_{50}: 0.014 \mathrm{mg} \mathrm{ml}^{-1}\right)$ than workers $\left(\mathrm{LC}_{50}: 0.09 \mathrm{mg} \mathrm{ml}^{-1}\right)$. Termiticidal activity from $O$. ficus indica cladodes was determined using preparations (extract and OfiL) at concentrations of $0.25,0.5,1.0$ and $1.5 \mathrm{mg} \mathrm{ml}^{-1}$ of protein (Paiva et al., 2011). The extract was termiticidal against workers at $1.5 \mathrm{mg} \mathrm{ml}^{-1}$, though it did not interfere in survival of soldiers. OfiL was more active than cladode extracts, showing a stronger termiticidal activity against workers ( $\mathrm{LC}_{50}$ of $\left.0.116 \mathrm{mg} \mathrm{ml}^{-1}\right)$. The lectin was active against soldiers only at $1.5 \mathrm{mg} \mathrm{ml}^{-1}$.

M. oleifera seeds were also sources of termiticidal preparations (Table 1). Bioassays used crude preparations (extracts and protein fractions) as well as purified lectins (cMoL and WSMoL) at concentrations of $0.125,0.25,0.5,1.0$ and $1.5 \mathrm{mg} \mathrm{ml}^{-1}$ of protein (Paiva et al., 2011). Both extracts containing cMoL and WSMoL were termiticidal on soldiers at $1.5 \mathrm{mg} \mathrm{ml}^{-}$ 1 , but only the protein fraction rich in WSMoL and pure WSMoL at $1.5 \mathrm{mg} \mathrm{ml}^{-1}$ interfered in the survival rate of soldiers. cMoL and WSMoL extracts $\left(1.0\right.$ and $\left.1.5 \mathrm{mg} \mathrm{ml}^{-1}\right)$, protein fraction from the WSMoL extract $\left(1.5 \mathrm{mg} \mathrm{ml}^{-1}\right)$, as well the isolated cMoL and WSMoL $(1.5$ $\mathrm{mg} \mathrm{ml}^{-1}$ ) were all able to workers.

The repellent activity of MuBL, MuHL, MuLL, BmoRoL, OfiL, WSMoL and cMoL has also been investigated. Bioassays were performed in petri plates filled up with agar containing one central well at which termites were placed, and peripheral wells at which filter papers soaked with lectin were put. None of the lectins showed repellent activity N. corniger, since it was observed that the termites did not avoid contact with lectin-treated wells (Figure 3A).

\subsection{Larvicidal activity of lectins against Aedes aegypti}

The mosquito A. aegypti is native to North Africa, but it is a cosmopolitan species widely spread in tropical and subtropical regions (Forattini and Brito, 2003). Females feed more 
frequently on blood than on plant sap, and have high affinity for human blood. Insect development occurs through the egg, larvae (four instars: L1, L2, L3 and L4), pupa and adult stages. Under favorable conditions of temperature, humidity and food availability, the period between the egg stage and adult emergence varies from 10 to 13 days (Forattini, 1965). A. aegypti is vector of human diseases of low (classic dengue) and high mortality (yellow fever and hemorrhagic dengue fever).

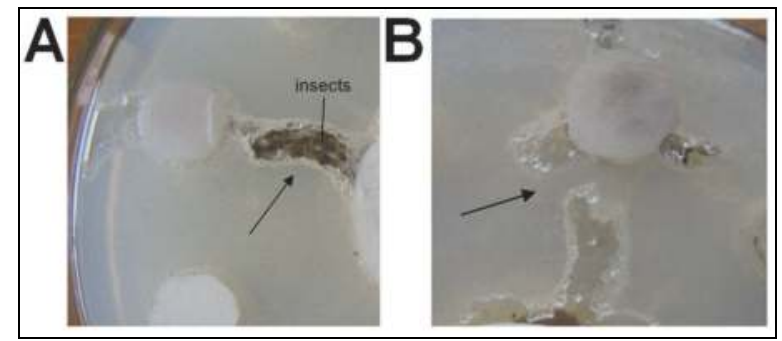

Fig. 3. Aspect of repellent activity assays. (A) non-repellent effect of lectin demonstrated by construction of tunnels in agar near a well containing lectin, and the galleries constructed in agar that remained open (arrow). (B) repellent action of methanolic extract from $M$.

urundeuva heartwood detected by presence of closed gallery (arrow) constructed in agar next to peripheral wells containing the extract.

Strategies for control of A. aegypti immature forms includes: elimination of reproduction sites, biological control by Bacillus thuringiensis serovar israelensis, and chemical control by larvicidal oils, repellents, organophosphorous, organophosphates and pyrethroids (Luna et al., 2004; Araújo et al., 2007). The control of mosquitoes using the insecticides Temephos, Malathion and Fenitrothion is the main measure adopted by public health programs; however, A. aegypti larvae have developed tolerance to these compounds, and this is one of the main problems in vector control programs (Poupardin et al., 2008; Melo-Santos et al., 2010).

M. oleifera seed extracts containing WSMoL interfered in the A. aegypti larval development (Figure 4). First larval instar (L1) incubated with extracts prepared with one, six and fifteen seeds $\left(\mathrm{SE}_{1}, \mathrm{SE}_{6}\right.$ and $\mathrm{SE}_{15}$ ) reached the last instar (L4) after longer development times than those recorded for the negative control (distilled water). The delay in larvae development promoted by $\mathrm{SE}_{6}$ and $\mathrm{SE}_{15}$ was greater than that caused by $\mathrm{SE}_{1}$, revealing a higher concentration of active principle (Coelho et al., 2009).

WSMoL and the lectins from M. urundeuva bark and heartwood (MuBL and MuHL) showed larvicidal activity against fourth-stage larvae in a concentration-dependent manner (Coelho et al., 2009; Sá et al., 2009c). Figure 5 shows that these lectins promoted larvae mortality with different efficiency; the values of lectin concentration ( $\mathrm{mg} \mathrm{ml}^{-1}$ ) required to kill $50 \%$ ( $\left.\mathrm{LC}_{50}\right)$ of larvae in $24 \mathrm{~h}$ were 0.125 (MuBL), 0.04 (MuHL) and 0.197 (WSMoL). The hemagglutinating activities of MuBL and MuHL were not affected by exposure to sunlight, indicating that these lectins were resistant to environmental conditions of radiation and temperature, an important characteristic to be used in A. aegypti control (Sá et al., 2009c).

WSMoL heated at $100{ }^{\circ} \mathrm{C}$ for $5 \mathrm{~h}$ did not show hemagglutinating and larvicidal activities; these data reveal that the native protein structure is a requirement for these biological properties to remain in place. The larvae treated with WSMoL showed morphological 
changes like hypertrophy of segments, increased gut volume and absence of epithelial layer that delimits the gut (Coelho et al., 2009).

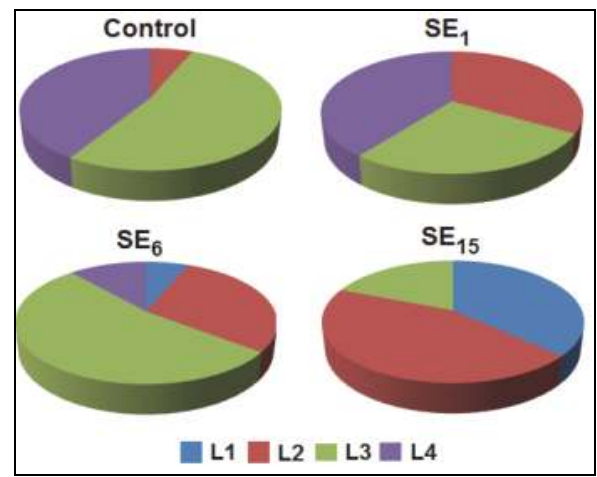

Fig. 4. Larval instar (\%) of A. aegypti after incubation with M. oleifera seed extracts prepared with one, six and fifteen seeds ( $\mathrm{SE}_{1}, \mathrm{SE}_{6}$ and $\mathrm{SE}_{15}$, respectively) for $72 \mathrm{~h}$.

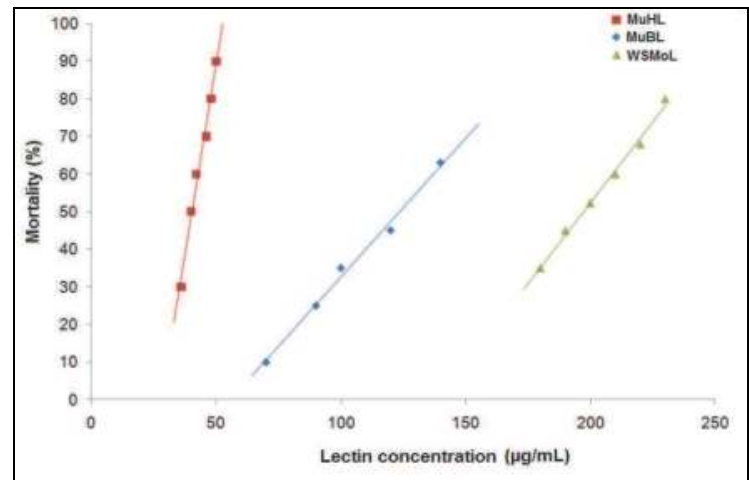

Fig. 5. Insecticidal activity of lectins from Moringa oleifera seeds (WSMoL) and Myracrodruon urundeuva bark (MuBL) and heartwood (MuHL) against $A$. aegypti fourth instar larvae (L4).

\section{Secondary metabolites}

Organic compounds produced by plants constitute a large and heterogeneous group known as secondary metabolites, characterized by a variety of structures and functions. They can be classified on the basis of chemical structure and composition, as nitrogen compounds (alkaloids, non-protein amino acids, amines, alcamides, cyanogenic glycosides and glucosinolates) and non-nitrogen compounds (monoterpenes, diterpenes, triterpenes, tetraterpenes, sesquiterpenes, saponins, flavonoids, steroids, coumarins).

Secondary metabolites may be found in several plant tissues. Differences in chemical properties and polarity of these molecules afford the use of different solvents for their extraction. Although aqueous extracts are usually rich in proteins, secondary metabolites can also be extracted by aqueous solutions. On the other hand, methanolic extracts generally contain large amounts of secondary metabolites with no protein content. 
Natural functions and applications of secondary metabolites have been investigated employing separation techniques to isolate them from plant extracts or synthetic methods to obtaining equivalent compounds. However, many of the in vivo functions of secondary metabolites remain unknown. These substances do not appear to participate directly in the growth and development of plant, but many of them can be associated with survival and adaptation, including metal transporters, symbiotic agents, hormones, differential effectors and defense molecules (Demain and Fang, 2000).

The synthesis of secondary metabolites with defense role can be induced by water stress as well as seasonal variations in temperature and luminosity or infection by pathogens (Bray et al., 2000; Bulbovas et al., 2005). Experiments that simulated mechanical stimulation and damage promoted by phytopatogenous insects in Glycine max leaves demonstrated that secondary metabolites (mainly y-aminobutyric acid) can be accumulated in this tissue, when submitted to injuries (Ramputh and Bown, 1996).

After ingestion by herbivores, secondary metabolites can induce damage through several and different mechanisms. Alkaloids act as agonists or antagonists of neurotransmitters, and neuroreceptors or can insert themselves into DNA or induce DNA alkylation. In this way, the ingestion of alkaloids may disrupt the replication and transcription in phytophagous organisms. Non-nitrogen secondary metabolites, such as phenols, terpenoids and saponins affect herbivores through less specific mechanisms. Tannins and phenols can interact with several proteins through hydrogen bonds or ionic interactions inducing conformational changes that can lead to loss of protein activity and function. Lipophilic terpenes can affect the integrity of biomembranes. Finally, saponins have cytotoxic and antimicrobial effects by interacting with cellular membranes, inducing pore formation and causing disturbances in cell permeability (Wink, 2003).

\subsection{Repellent activity of secondary metabolites from Myracrodruon urundeuva heartwood against Nasutitermes corniger}

Methanolic extract from M. urundeuva heartwood contained secondary metabolites cinamic derivatives, flavonoids, gallic acid, luteolin, proanthocyanidins, hydrolysable tannins, and leucoanthocyanidins (Figure 6). Termiticidal and repellence bioassays revealed that the extract showed no termiticidal activity, though it induced repellent effect against $N$. corniger (Sá et al., 2009a). Insects closed the galleries constructed in agar next to peripheral wells containing the extract (Figure 3B). The presence of harmful compounds can be detected by insects through chemical receptors like olfactory or gustatory sensilla that detect chemicals with high or low-volatility, respectively (Bohbot and Vogt, 2005). Thus, termites can be repelled or attracted by a substance, depending on its chemical composition.

The studies on M. urundeuva heartwood indicate that two mechanisms seem to be involved in the resistance of this tissue against $N$. corniger: prevention of the arrival and attack of $N$. corniger by repellent action of secondary metabolites, and death of termites induced by MuHL, the heartwood lectin (Sá et al., 2009a).

\section{Acknowledgments}

The authors express their gratitude to the Conselho Nacional de Desenvolvimento Científico e Tecnológico (CNPq) for research grants and fellowships (PMGP, LCBBC). We are also grateful to the Fundação de Amparo à Ciência e Tecnologia do Estado de Pernambuco (FACEPE) and the Coordenação de Aperfeiçoamento de Pessoal de Nível Superior (CAPES) 
for financial support. We thank Emmanuel Viana Pontual for design of the figure 1 and Felix Nonnenmacher for English editing.

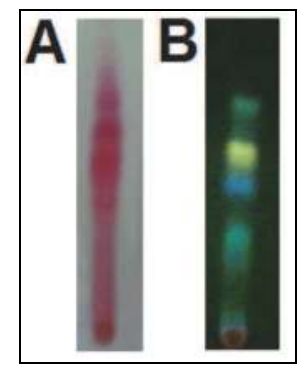

Fig. 6. Secondary metabolites from methanolic extract revealed by thin layer chromatography (TLC). (A) proanthocyanidins, hydrolysable tannins and leucoanthocyanidins. (B) kaempferol (green), quercetin (yellow) and gallic acid (blue).

\section{References}

Almeida-Cortez, J. S.; Cortez, P.H.M.; Franco, J.M.V. \& Uzunian, A. (2007) Caatinga - Coleção Biomas do Brasil (1st ed), Harbra, ISBN 978-85-294-0323-1, São Paulo, Brazil.

Angus, R.B.; Dellow, J.; Winder, C. \& Credland, P.F. (2011). Karyotype differences among four species of Callosobruchus Pic (Coleoptera: Bruchidae). Journal of Stored Products Research, Vol. 47, No. 2, (April 2011), pp. 76-81, ISSN 0022-474X

Araújo, A.P.; Melo-Santos, M.A.V.; Carlos, S.O.; Rios, E.M.M.M. \& Regis, L. (2007). Evaluation of an experimental product based on Bacillus thuringiensis sorovar. israelensis against Aedes aegypti larvae (Diptera: Culicidae). Biological Control, Vol. 41, No. 3, (June 2007), pp. 339-347, ISSN 1049-9644

Bandyopadhyay, S.; Roy, A. \& Das, S. (2001). Binding of garlic (Allium sativum) leaf lectin to the gut receptors of homopteran pests is correlated to its insecticidal activity. Plant Science, Vol. 161, No. 5, (October 2001), pp. 1025-1033, ISSN 0168-9452

Bennett, S.M. (2003). Ephestia kuehniella (Mill or Flour Moth) (can also be Mediterranean Flour Moth), in: The PiedPiper, 7 July 2011, Available from: <http://www.thepiedpiper.co.uk/th7e.htm>

Bohbot, J. \& Vogt, R.G. (2005). Antennal expressed genes of the yellow fever mosquito (Aedes aegypti L.); characterization of odorant-binding protein 10 and takeout. Insect Biochemistry and Molecular Biology, Vol. 35, No. 9, (September 2005), pp. 961-979, ISSN 0965-1748.

Bray, E.A.; Bailey-Serres, J. \& Weretilnyk, E (2000). Responses to abiotic stresses, In: Biochemistry \& Molecular Biology of Plants, Buchanan, B.B.; Gruissen, W. \& Jones L.R. (eds), pp. 1158-1203, American Society of Plant Physiologists, ISBN 0-943088-39-9, New York, US

Bulbovas, P.; Rinaldi, M.C.S.; Delitti, W.B.C. \& Domingos, M. (2005). Variação sazonal em antioxidantes em folhas de plantas jovens de Caesalpinia echinata Lam. (pau-brasil). Revista Brasileira de Botânica, Vol. 28, No. 4, (December 2005), pp. 687-696, ISSN 0100-8404 
Carlini, C.R. \& Grossi-de-Sá, M.F. (2002). Plant toxic proteins with insecticidal properties. A review on their potential as bioinsecticides. Toxicon, Vol. 40, No. 11, (November 2002), pp. 1515-1539, ISSN 0041-0101

Coelho, J.S.; Santos, N.D.L.; Napoleão, T.H.; Gomes, F.S.; Ferreira, R.S.; Zingali, R.B.; Coelho, L.C.B.B.; Leite, S.P.; Navarro, D.M.A.F. \& Paiva, P.M.G. (2009). Effect of Moringa oleifera lectin on development and mortality of Aedes aegypti larvae. Chemosphere, Vol. 77, No. 7, (November 2009), pp. 934-938, ISSN 0045-6535

Coelho, L.C.B.B. \& Silva, M.B.R. (2000). Simple method to purify milligram quantities of the galactose-specific lectin from the leaves of Bauhinia monandra. Phytochemical Analysis, Vol. 11, No. 5, pp. 295-300, ISSN 0958-0344

Coelho, M.B.; Marangoni, S. \& Macedo, M.L.R. (2007). Insecticidal action of Annona coriacea lectin against the flour moth Anagasta kuehniella and the rice moth Corcyra cephalonica (Lepidoptera: Pyralidae). Comparative Biochemistry and Physiology Part C, Toxicology and Pharmacology Vol. 146, No. 3, (September 2007), pp. 406-414, ISSN 1532-0456

Credland, P.F. \& Dendy, J. (1992). Intraspecific variation in binomic characters of the Mexican bean weevil, Zabrotes subfasciatus. Entomologia Experimentalis et Applicata, Vol. 65, No. 1, (October 1992), pp. 39-47, ISSN 1570-7458

Demain, A.L. \& Fang A. (2000). The natural functions of secondary metabolites. Advances in Biochemical Engineering Biotechnology. Vol. 69, (Year 2000), pp. 1-39, ISSN 0724-6145

Edvardsson, M. \& Tregenza, T. (2005). Why do male Callosobruchus maculatus harm their mates? Behavioral Ecology, Vol. 16, No. 4, (July/August 2005), pp. 788-793, ISSN 1045-2249

Edwards, P.J.; Wratten, S.D. (1980). Ecology of insect-plant interactions. Edward Arnold, ISBN 9780713128031, London, England

Eisemann, C.H.; Donaldson, R.A.; Pearson, R.D.; Cadogan, L.C.; Vacuolo, T. \& Tellam, R.L. (1994). Larvicidal activity of lectins on Lucilia cuprina: mechanism of action. Entomologia Experimentalis et Applicata, Vol. 72, No. 1, (July 1994), pp. 1-10, ISSN 1570-7458

Ferreira, R.S.; Napoleão, T.H.; Santos, A.F.S.; Sá, R.A.; Carneiro-da-Cunha, M.G.; Morais, M.M.C.; Silva-Lucca, R.A.; Oliva, M.L.V.; Coelho, L.C.B.B. \& Paiva, P.M.G. (2011) Coagulant and antibacterial activities of the water-soluble seed lectin from Moringa oleifera. Letters in Applied Microbiology, Vol. 53, No. 2, (August 2011), pp. 186-192 ISSN 1472-765X

Fitches, E.; Woodhouse, S.D.; Edwards, J.P. \& Gatehouse, J.A. (2001). In vitro and in vivo binding of snowdrop (Galanthus nivalis agglutinin; GNA) and jackbean (Canavalia ensiformis; Con A) lectins within tomato moth (Lacanobia oleracea) larvae; mechanisms of insecticidal action. Journal of Insect Physiology, Vol. 47, No. 7, (July 2011), pp. 777-787, ISSN 0022-1910

Fitches, E.; Philip, J.; Hinchliffe, G.; Vercruysse, L.; Chougule, N. \& Gatehouse, J.A. (2008). An evaluation of garlic lectin as an alternative carrier domain for insecticidal fusion proteins. Insect Science, Vol. 15, No. 6, (December 2008), pp. 483-495, ISSN 1744-7917

Forattini, O.P. (1965). Entomologia Médica, volume 2 (2nd ed), Editora da Universidade de São Paulo, São Paulo, Brazil. 
Forattini, O.P.; Brito, M. (2003). Household water resevoirs and control of Aedes aegypti. Revista de Saúde Pública, Vol. 37, No. 5, (October 2003), pp. 676-677, ISSN 0034-8910

Galati, E.M.; Monforte, M.T.; Tripodo, M.N.; D'Aquino, A. \& Mondello, M.R. (2001). Antiulcer activity of Opuntia ficus indica (L) Mill. (Cactaceae): ultrastructural study. Journal of Ethnopharmacology, Vol. 76, No. 1, (June 2001), pp. 1-9, ISSN 0378-8741

Galati, E.M.; c Miceli, N. \& Monforte, M.T. (2002). Biological effect of Opuntia ficus indica (L) Mill. (Cactaceae) waste matter. Note I: diuretic activity. Journal of Ethnopharmacology, Vol. 79, No. 1, (February 2002), pp. 17-21, ISSN 0378-8741

Gallo, D.; Nakano, O.; Neto, S.S.; Carvalho, R.P.L.; Batista, G.C.; Filho, E.B.; Parra, J.R.P.; Zucchi, R.A.; Alves, S.B.; Vendramim, J.D.; Marchini, L.C.; Lopes, J.R.S. \& Omoto, C. (2002). Entomologia agrícola (1st ed), FEALQ, ISBN 85-7133-011-5, Piracicaba, Brazil.

Gassenschmidt, U.; Jany, K.D.; Tauscher, B. \& Nierbergall, H. (1995). Isolation and characterization of a flocculating protein from Moringa oleifera Lam. Biochimica et Biophysica Acta, Vol. 1243, No. 3, (13 April 1995), pp. 477-481, ISSN 0304-4165

Ghebremichael, K.A.; Gunaratna, K.R.; Henriksson, H.; Brumer, H.; Dalhammar, G. (2005). A simple purification and activity assay of the coagulant protein from Moringa oleifera seed. Water Research, Vol. 39, No. 11, (June 2005), pp. 2338-2344, ISSN 00431354

Harper, M.S.; Hopkins, T.L. \& Czapla, T.H. (1998). Effect of wheat germ agglutinin on the formation and structure of the peritrophic membrane in European corn borer (Ostrinia nubilalis) larvae. Tissue and Cell, Vol. 30, No. 2, (April 1998), pp. 166-176, ISSN 0040-8166

Hegedus, D.; Erlandson, M.; Gillott, C.; Toprak, U. (2009). New Insights into Peritrophic Matrix Synthesis, Architecture, and Function. Annual Review of Entomology, Vol. 54, (Year 2009), pp. 285-302, ISSN 0066-4170

Hinata, K. \& Nishio, T. (1981). Con A-Peroxidase method: an improved procedure for staining S-glycoproteins in cellulose-acetate electrofocusing in crucifers. Theoretical and Applied Genetics, Vol. 60, No. 5, (September 1981), pp. 281-283, ISSN 0040-5752

Hogervorst, P.A.M.; Ferry, N.; Gatehouse, A.M.R.; Wäckers, F.L. \& Romeis, J. (2006). Direct effects of snowdrop lectin (GNA) on larvae of three aphid predators and fate of GNA after ingestion. Journal of Insect Physiology, Vol. 52, No. 6, (June 2006), pp. 614624, ISSN 0022-1910

Isidro, R.; Sales, F.J.M.; Cavada, B.S.; Grangeiro, T.B. \& Moreira, R.A. (2001) Ação de lectina de sementes de Canavalia brasiliensis Mart. sobre o comportamento da saúva do Nordeste (Atta opaciceps Borgmeier, 1939). Revista de la Facultad de Agronomía (Maracay), Vol. 27, No. 2, p. 77-86, ISSN 1856-5573

Judd, W.S.; Campbell, C.S.; Kellog, E.A.; Stevens, P.F. \& Donoghue, M.J. (2007). Plant Systematics: A Phylogenetic Approach (3rd ed), Sinauer Associates Inc., ISBN 9780878934072, Sunderland, US.

Kaur, M.; Singh, K.; Rup, P.J.; Saxena, A.K.; Khan, R.H.; Ashraf, M.T.; Kamboj, S.S.; Singh, J. (2006). A tuber lectin from Arisaema helleborifolium Schott with anti-insect activity against melon fruit fly, Bactrocera cucurbitae (Coquillett) and anti-cancer effect on 
human cancer cell. Archives of Biochemistry and Biophysics, Vol. 445, No. 1, (1 January 2006), pp. 156-165, ISSN 0003-9861

Kawsar, S.M.; Fujii, Y.; Matsumoto, R.; Ichikawa, T.; Tateno, H.; Hirabayashi, J.; Yasumitsu, H.; Dogasaki, C.; Hosono, M.; Nitta, K.; Hamako, J.; Matsui, T. \& Ozeki, Y. (2008). Isolation, purification, characterization and glycan-binding profile of a Dgalactoside specific lectin from the marine sponge, Halichondria okadai. Comparative Biochemistry and Physiology Part B: Biochemistry and Molecular Biology, Vol. 150, No. 4, (August 2008), pp. 349-357, ISSN 1096-4959

Laemmli, U.K. (1970). Cleavage of structural proteins during the assembly of the head of bacteriophage T4. Nature, Vol. 227, (August 1970), pp. 680-685, ISSN 0028-0836

Leite, E.J. (2002). State of knowledge on Myracrodruon urundeuva Fr. Allemão (Anacardiaceae) for genetic conservation in Brazil. Perspectives in Plant Ecology, Evolution and Systematics, Vol. 5, No. 3, pp. 193-206, ISSN 1433-8319

Li, H.M.; Sun, L.; Mittapalli, O.; Muir, W.M.; Xie, J.; Wu, J.; Schemerhorn, B.J.; Sun, W.; Pittendrigh, B.R. \&, Murdock, L.L. (2009). Transcriptional signatures in response to wheat germ agglutinin and starvation in Drosophila melanogaster larval midgut. Insect Molecular Biology, Vol. 18, No. 1, (February 2009), pp. 21-31, ISSN 1365-2583

Loganathan, M.; Jayas, D.S.; Fields, P.G. \& White, N.D.G. (2011). Low and high temperatures for the control of cowpea beetle, Callosobruchus maculatus (F.) (Coleoptera: Bruchidae) in chickpeas. Journal of Stored Products Research, Vol. 47, No. 3, (July 2011), pp. 244-248, ISSN 0022-474X

Luna, J.E.D.; Martins, M.F.; Anjos, A.T.; Kuwabaro, E.F. \& Navarro-Silva, M.A. (2004). Susceptibilidade de Aedes aegypti aos inseticidas temephos e cipermetrina, Brasil. Revista de Saúde Pública, Vol. 38, No. 6, (December 2004), pp. 842-843, ISSN 00348910

Macedo, M.L.R.; Damico, D.C.S.; Freire, M.G.M.; Toyama, M.H.; Marangoni, S. \& Novello, J.C. (2003). Purification and characterization of an $\mathrm{N}$-acetylglucosamine-binding lectin from Koelreuteria paniculata seeds and its effect on the larval development of Callosobruchus maculatus (Coleoptera: Bruchidae) and Anagasta kuehniella (Lepidoptera: Pyralidae). Journal of Agricultural and Food Chemistry, Vol. 51, No. 10, (April 2003), pp. 2980-2986, ISSN 0021-8561

Macedo, M.L.R.; Castro, M.M. \& Freire, M.G.M. (2004). Mechanisms of the insecticidal action of TEL (Talisia esculenta lectin) against Callosobruchus maculatus (Coleoptera: Bruchidae). Archives of Insect Biochemistry and Physiology, Vol. 56, No. 2, (June 2004), pp. 84-96, ISSN 1520-6327

Macedo, M.L.R.; Freire, M.G.M.; Silva, M.B.R. \& Coelho, L.C.B.B. (2007). Insecticidal action of Bauhinia monandra leaf lectin (BmoLL) against Anagasta kuehniella (Lepidoptera: Pyralidae), Zabrotes subfasciatus and Callosobruchus maculatus (Coleoptera: Bruchidae). Comparative Biochemistry and Physiology Part A, Molecular and Integrative Physiology, Vol. 146, No. 4, (April 2007), pp. 486-498, ISSN 1095-6433

Mainieri, C.; Chimelo, J.P. (1989). Fichas de características de madeiras brasileiras. IPT, ISBN 978850-9000-46-2 São Paulo, Brazil.

Melo-Santos, M.A.V., Varjal-Melo, J.J.M., Araújo, A.P., Gomes, T.C.S., Paiva, M.H.S., Regis, L.N., Furtado, A.F., Magalhães, T., Macoris, M.L.G., Andrighetti, M.T.M. \& Ayres, 
C.F.J. (2010). Resistance to the organophosphate temephos: mechanisms, evolution and reversion in an Aedes aegypti laboratory strain from Brazil. Acta Tropica, Vol. 113, No. 2, (February 2010), pp. 180-189, ISSN 0001-706X

Monath, T.P. (2008) Treatment of yellow fever. Antiviral Research, Vol. 78, No. 1, (April 2008), pp. 116-124, ISSN 0166-3542

Moreno, F.B.; Oliveira, T. M.; Martil, D.E.; Viçoti, M.M.; Bezerra, G.A.; Abrego, J.R.; Cavada, B.S. \& Azevedo Jr., W.F. (2008). Identification of a new quaternary association for legume lectins. Journal of Structural Biology, Vol. 161, No. 2, (February 2008), pp. 133-143, ISSN 1047-8477

Murdock, L.L.; Huesing, J.E.; Nielsen, S.S.; Pratt, R.C. \& Shade, R.E. (1990). Biological effects of plant lectins on the cowpea weevil. Phytochemistry, Vol. 29, No. 1, pp. 85-89, ISSN 0031-9422

Napoleão, T.H.; Gomes, F.S.; Lima, T.A.; Santos, N.D.L.; Sá, R.A.; Albuquerque, A.C.; Coelho, L.C.B.B. \& Paiva, P.M.G. (2011). Termiticidal activity of lectins from Myracrodruon urundeuva against Nasutitermes corniger and its mechanisms. International Biodeterioration \& Biodegradation, Vol. 65, No. 1, (January 2011), pp. $52-$ 59, ISSN 0964-8305

Nasi, A.; Picariello, G.; Ferranti, P. (2009). Proteomic approaches to study structure, functions and toxicity of legume seeds lectins. Perspectives for the assessment of food quality and safety. Journal of Proteomics, Vol. 72, No. 3, (13 April 2009), pp. 527538, ISSN 1874-3919

Ndabigengesere, A.; Narasiah, K.S. \& Talbot, B.G. (1995). Active agents and mechanism of coagulation of turbid waters using Moringa oleifera. Water Research, Vol. 29, No. 2, (February 1995), pp. 703-710, ISSN 0043-1354

Okuda, T., Baes, A.U., Nishijima, W. \& Okada, M. (2001). Isolation and characterization of coagulant extracted from Moringa oleifera seed by salt solution. Water Research, Vol. 35, No. 2, (February 2001), pp. 405-410, ISSN 0043-1354

Oliveira, C.F.R.; Luz, L.A.; Paiva, P.M.G.; Coelho, L.C.B.B.; Marangoni, S. \& Macedo, M.L.R. (2011). Evaluation of seed coagulant Moringa oleifera lectin (cMoL) as a bioinsecticidal tool with potential for the control of insects. Process Biochemistry, Vol. 46, No. 2, (February 2011), pp. 498-504, ISSN 1359-5113

Paes, J.B.; Morais, V.M. \& Lima, CR (2002). Resistência das madeiras de aroeira (Myracrodruon urundeuva), cássia (Senna siamea) e ipê (Tabebuia impetiginosa) a fungos e cupins xilófagos em condições de laboratório. Floresta e Ambiente, Vol. 9, No. 1, (Year 2002), pp. 135-144, ISSN 1415-0980

Paes, J.B.; Melo, R.R.; Lima, C.R. \& Oliveira, E. (2007). Resistência natural de sete madeiras ao cupim subterrâneo (Nasutitermes corniger Motsch.) em ensaio de preferência alimentar. Revista Brasileira de Ciências Agrárias, Vol. 2, No. 1, (January-March 2007), pp. 57-62, ISSN 1981-0997

Paiva, P.M.G.; Santana, G.M.S.; Souza, I.F.A.C.; Albuquerque, L.P.; Agra-Neto, A.C.; Albuquerque, A.C.; Luz, L.A.; Napoleão, T.H.; Coelho, L.C.B.B. (2011). Effect of lectins from Opuntia ficus indica cladodes and Moringa oleifera seeds on survival of Nasutitermes corniger. International Biodeterioration \& Biodegradation, doi:10.1016/ j.ibiod.2011.05.008. 
Peumans, W.J.; Van Damme, E.J.M. (1995). Lectins as plant defense proteins. Plant Physiology, Vol. 109, No. 2, (October 1995), pp. 347-352, ISSN 0032-0889

Pharmacia Fine Chemicals (1980). Polyacrylamide Electrophoresis, Laboratory Techniques, Pharmacia [Pamphlet], ASIN B002O1CL3C, Uppsala, Sweden.

Poupardin, R.; Reynaud, S.; Strode, C.; Ranson, H.; Vontas, J.; David, J.P. (2008). Crossinduction of detoxification genes by environmental xenobiotics and insecticides in the mosquito Aedes aegypti: impact on larval tolerance to chemical insecticides. Insect Biochemistry and Molecular Biology, Vol. 38, No. 5, (May 2008), pp. 540-551, ISSN 0965-1748

Powell, K.S.; Gatehouse, A.M.R.; Hilder, V.A.; Gatehouse, J.A. (1995). Antifeedant effects of plant-lectins and an enzyme on the adult stage of the rice brown planthopper, Nilaparvata lugens. Entomologia Experimentalis et Applicata, Vol. 75, No. 1, (April 1995), pp. 51-59, ISSN 1570-7458

Ramputh, A-I. \& Brown, A.W. (1996). Rapid $\mathrm{y}$-aminobutyric acid synthesis and the lnhibition of the growth and development of oblique-banded leaf-roller larvae. Plant Physiology, Vol. 111, No. 4, (August 1996), pp. 1349-1352, ISSN 0032-0889

Rao, V.S.; Viana, G.S.B.; Menezes, A.M.S.; Gadelha, M.G.T. (1987). Studies on the antiulcerogenic activity of Astronium urundeuva. Brazilian Journal of Medical and Biological Research, Vol. 20, No. 6, pp. 253-256, ISSN 0100-879X

Reisfeld, R.A., Lewis, U.J. \& Williams, D.E. (1962). Disk eletrophoresis of basic protein and peptides on polyacrylamide gels. Nature, Vol. 195 (July 1962), pp. 281-283, ISSN 0028-0836

Rolim, L.A.D.M.M.; Macedo, M.F.S.; Sisenando, H.A.; Napoleão, T.H.; Felzenswalb, I.; Aiub, C.A.F.; Coelho, L.C.B.B.; Medeiros, S.R.B. \& Paiva, P.M.G. (2011). Genotoxicity evaluation of Moringa oleifera seed extract and lectin. Journal of Food Science, Vol. 76, No. 2, (March 2011), pp. T53-T58, ISSN 1750-3841

Sá, R.A.; Argolo, A.C.C.; Napoleão, T.H.; Gomes, F.S.; Santos, N.D.L.; Melo, C.M.L.; Albuquerque, A.C.; Xavier, H.S.; Coelho, L.C.B.B.; Bieber, L.W. \& Paiva, P.M.G. (2009a). Antioxidant, Fusarium growth inhibition and Nasutitermes corniger repellent activities of secondary metabolites from Myracrodruon urundeuva heartwood. International Biodeterioration \& Biodegradation, Vol. 63, No. 4, (June 2009), pp. 470477, ISSN 0964-8305

Sá, R.A.; Gomes, F.S.; Napoleão, T.H.; Santos, N.D.L.; Melo, C.M.L.; Gusmão, N.B.; Coelho, L.C.B.B.; Paiva, P.M.G. \& Bieber, L.W. (2009b). Antibacterial and antifungal activities of Myracrodruon urundeuva heartwood. Wood Science and Technology, Vol. 43, No. 1-2, (February 2009), pp. 85-95, ISSN 1432-5225

Sá, R.A.; Napoleão, T.H.; Santos, N.D.L.; Gomes, F.S.; Albuquerque, A.C.; Xavier, H.S.; Coelho, L.C.B.B.; Bieber, L.W. \& Paiva, P.M.G. (2008). Induction of mortality on Nasutitermes corniger (Isoptera, Termitidae) by Myracrodruon urundeuva heartwood lectin. International Biodeterioration \& Biodegradation, Vol. 62, No. 4, (December 2008), pp. 460-464, ISSN 0964-8305

Sá, R.A.; Santos, N.D.L.; da Silva, C.S.B.; Napoleão, T.H.; Gomes, F.S.; Cavada, B.S.; Coelho, L.C.B.B.; Navarro, D.M.A.F.; Bieber, L.W. \& Paiva, P.M.G. (2009c). Larvicidal activity of lectins from Myracrodruon urundeuva on Aedes aegypti. Comparative 
Biochemistry and Physiology Part C, Toxicology and Pharmacology, Vol. 149, No. 3, (April 2009), pp. 300-306, ISSN 1532-0456

Santana, G.M.S.; Albuquerque, L.P.; Simões, D.A.; Gusmão, N.B.; Coelho, L.C.B.B. \& Paiva, P.M.G. 2009. Isolation of lectin from Opuntia ficus indica cladodes. Acta Horticulturae, Vol. 811, (February 2009), pp. 281-286, ISSN 0567-7572

Santana, M.A.; Santos, A.M.C.; Oliveira, M.E.; de Oliveira, J.S.; Baba, E.H.; Santoro, M.M.; de Andrade, M.H.G. (2008). A novel and efficient and low-cost methodology for purification of Macrotyloma axillare (Leguminosae) seed lectin. International Journal of Biological Macromolecules, Vol. 43, No. 4, (November 2008), pp. 352-358, ISSN 0141-8130

Santos, A.F.S.; Argolo, A.C.C.; Coelho, L.C.B.B.; Paiva, P.M.G. (2005). Detection of water soluble lectin and antioxidant component from Moringa oleifera seeds. Water Research, Vol. 39, No. 6, (March 2005), pp. 975-980, ISSN 0043-1354

Santos, A.F.S.; Carneiro-da-Cunha, M.G.; Teixeira, J.A.; Paiva, P.M.G.; Coelho, L.C.B.B. \& Nogueira, R.M.O.B. (2011a). Interaction of Moringa oleifera seed lectin with humic acid. Chemical Papers, Vol. 65, No. 4, (August 2011), pp. 406-411, ISSN 1336-9075

Santos, A.F.S.; Luz, L.A.; Argolo, A.C.C.; Teixeira, J.A.; Paiva, P.M.G. \& Coelho, L.C.B.B. (2009). Isolation of a seed coagulant Moringa oleifera lectin. Process Biochemistry, Vol. 44, No. 4, (April 2009), pp. 504-508, ISSN 1359-5113

Santos, A.F.S.; Paiva, P.M.G.; Teixeira, J.A.C.; Brito, A.G.; Coelho, L.C.B.B. \& Nogueira, R. (2011b). Coagulant properties of Moringa oleifera protein preparations: application to humic acids removal. Environmental Technology, doi:0.1080/ 09593330.2010.550323, ISSN 1479-487X

Sari, L.T.; Ribeiro-Costa, C.S. \& Pereira, P.R.V.S. (2003). Biological aspects of Zabrotes subfasciatus (Bohemann, 1833) (Coleoptera, Bruchidae) on Phaseolus vulgaris L., cv. Carioca (Fabaceae), under laboratory conditions. Revista Brasileira de Entomologia, Vol. 47, No. 4, (December 2003), pp. 621-624, ISSN 0085-5626

Scheffrahn, R.H.; Cabrera, B.J.; Kern Jr., W.J. \& Su, N.Y. (2002). Nasutitermes costalis (Isoptera: Termitidae) in Florida: first record of a non-endemic establishment by a higher termite. Florida Entomologist, Vol. 85, No. 1, (March 2002), pp. 273-275, ISSN 00154040

Scheffrahn, R.H.; Krecek, J.; Szalanski, A.L. \& Austin, J.W. (2005). Synonymy of neotropical arboreal termites Nasutitermes corniger and $N$. costalis (Isoptera: Termitidae: Nasutitermitinae) with evidence from morphology, genetics, and biogeography. Annals of the Entomological Society of America, Vol. 98, No. 3, (May 2005), pp. 273-281, ISSN 0013-8746

Sharon, N. \& Lis, H. (2001). The structural basis for carbohydrate recognition by lectins. Advances in Experimental Medicine and Biology, Vol. 491, pp. 1-16.

Sharon, N. \& Lis, H. (2007). Lectins (2nd ed), Springer, ISBN 978-1-4020-6605-4, Dordrecht, The Netherlands.

Silva, M.D.C.; Sá, R.A.; Napoleão, T.H.; Gomes, F.S.; Santos, N.D.L.; Albuquerque, A.C.; Xavier, H.S.; Paiva, P.M.G.; Correia, M.T.S. \& Coelho, L.C.B.B. (2009). Purified Cladonia verticillaris lichen lectin: Insecticidal activity on Nasutitermes corniger 
(Isoptera: Termitidae). International Biodeterioration \& Biodegradation, Vol. 63, No. 3, (April 2009), pp. 334-340, ISSN 0964-8305

Sisenando, H.A.A.A.C.N.; Macedo, M.F.S.; Saturnini, A.C.R.D.; Coelho, L.C.B.B. \& Medeiros, S.R.B. (2009). Evaluation of the genotoxic potential of Bauhinia monandra leaf lectin (BmoLL). Food and Chemical Toxicology, Vol. 47, No. 2, (February 2009), pp. 303-308, ISSN 0278-6915

Souza, A.J.; Santos, P.O.; Pinto, M.S.T.; Wermelinger, T.T.; Ribeiro, E.S.; Souza, S.C.; Deus, M.F.; Souza, M.C.; Xavier-Filho, J.; Fernandes, K.V.S. \& Oliveira, A.E.A. (2011a). Natural seed coats provide protection against penetration by Callosobruchus maculatus (Coleoptera: Bruchidae) larvae. Crop Protection, Vol. 30, No. 6, (June 2011), pp. 651-657, ISSN 0261-2194

Souza, J.D.; Silva, M.B.R.; Argolo, A.C.C.; Napoleão, T.H.; Sá, R.A.; Correia, M.T.S.; Paiva, P.M.G.; Silva, M.D.C. \& Coelho, L.C.B.B. (2011b). A new Bauhinia monandra galactose-specific lectin purified in milligram quantities from secondary roots with antifungal and termiticidal activities. International Biodeterioration and Biodegradation, Vol. 65, No. 5, (August 2011), pp. 696-702, ISSN 0964-8305

Tegegne, F.; Kijora, C. \& Peters, K. (2007). Study on the optimal level of cactus pear (Opuntia ficus-indica) supplementation to sheep and its contribution as source of water, Small Ruminant Research, Vol. 72, No. 2-3, (October 2007), pp. 157-164, ISSN 0921-4488

Tellam, R.L.; Wijffels, G. \& Wiladsen, P. (1999). Peritrophic matrix proteins. Insect Biochemistry and Molecular Biology, Vol. 29, No. 2, (February 1999), pp, 87-101, ISSN 0965-1748.

Tounsi, S.; Dammak, M.; Rebaî, A. \& Jaoua, S. (2005). Response of larval Ephestia kuehniella (Lepidoptera: Pyralidae) to individual Bacillus thuringiensis kurstaki toxins and toxin mixtures. Biological Control, Vol. 35, No. 1, (October 2005), pp. 27-31, ISSN 1049-9644

Trombetta, D.; Puglia, C.; Perri, D.; Licata, A.; Pergolizzi, S.; Lauriano, E.R.; De Pasquale, A.; Saija, A. \& Bonina, F.P. (2006). Effect of polysaccharides from Opuntia ficus indica (L.) cladodes on the healing of dermal wounds in the rat. Phytomedicine, Vol. 13, No. 5, (9 May 2006), pp. 352-358, ISSN $0944-7113$

Vandenborre, G.; Smagghe, G. \& Van Damme, E.J.M. (2011). Plant lectins as defense proteins against phytophagous insects. Phytochemistry, Vol. 72, No. 13 (September 2011), pp. 1538-1550, ISSN 0031-9422

Wink, M. (2003). Evolution of secondary metabolites from an ecological and molecular phylogenetic perspective. Phytochemistry, Vol. 64, No. 1, (September 2003), pp. 3-19, ISSN 0031-9422

Wu, A.M.; Song, S.C.; Tsai, M.S., Herp, A. (2001) A guide to the carbohydrate specificities of applied lectins-2 (updated in 2000). Advances in Experimental Medicine and Biology, Vol. 491, pp. 551-585, ISSN 0065-2598

Yu, L.G.; Fernig, D.G.; White, M.R.H.; Spiller, D.G.; Appleton, P.; Evans, R.C.; Grierson, I.; Smith, J.A.; Davies, H.; Gerasimenko, O.V.; Petersen, O.H.; Milton, J.D. \& Rhodes, J.M. (1999). Edible mushroom (Agaricus bisporus) lectin, which reversibly inhibits epithelial cell proliferation, blocks nuclear localization sequence-dependent nuclear protein import. The Journal of Biological Chemistry, Vol. 274, No. 8, (February 1999), pp. 4890-4899, ISSN 0021-9258 
Zhu-Salzman, K.; Salzman, R.A. (2001). Functional mechanics of the plant defensive Griffonia simplicifolia lectin II: resistance to proteolysis is independent of glycoconjugate binding in the insect gut. Journal of Economic Entomology, Vol. 94, No. 5, (October 2001), pp. 1280-1284, ISSN 0022-0493

Zhu-Salzman, K.; Shade, R.E.; Koiwa, H.; Salzman, R.A.; Narasimhan, M.; Bressan, R.A.; Hasegawa, P.M. \& Murdock, L.L. (1998). Carbohydrate binding and resistance to proteolysis control insecticidal activity of Griffonia simplicifolia lectin II. Proceedings of the National Academy of Sciences of the United States of America, Vol. 95, (December 1998), pp. 15123-15128, ISSN 0027-8424 


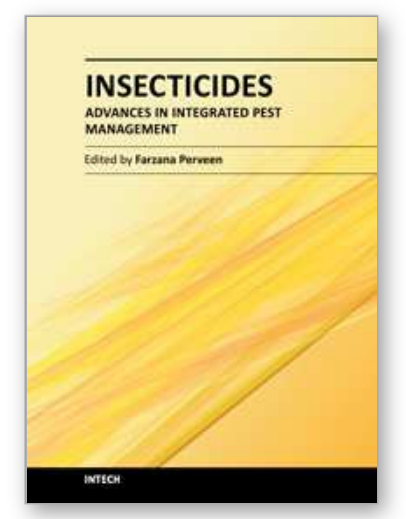

\author{
Insecticides - Advances in Integrated Pest Management \\ Edited by Dr. Farzana Perveen
}

ISBN 978-953-307-780-2

Hard cover, 708 pages

Publisher InTech

Published online 05, January, 2012

Published in print edition January, 2012

This book contains 30 Chapters divided into 5 Sections. Section A covers integrated pest management, alternative insect control strategies, ecological impact of insecticides as well as pesticides and drugs of forensic interest. Section B is dedicated to chemical control and health risks, applications for insecticides, metabolism of pesticides by human cytochrome p450, etc. Section $\mathrm{C}$ provides biochemical analyses of action of chlorfluazuron, pest control effects on seed yield, chemical ecology, quality control, development of ideal insecticide, insecticide resistance, etc. Section $D$ reviews current analytical methods, electroanalysis of insecticides, insecticide activity and secondary metabolites. Section E provides data contributing to better understanding of biological control through Bacillus sphaericus and B. thuringiensis, entomopathogenic nematodes insecticides, vector-borne disease, etc. The subject matter in this book should attract the reader's concern to support rational decisions regarding the use of pesticides.

\title{
How to reference
}

In order to correctly reference this scholarly work, feel free to copy and paste the following:

Patrícia M.G. Paiva, Thiago H. Napoleão, Roberto A. Sá and Luana C.B.B. Coelho (2012). Insecticide Activity of Lectins and Secondary Metabolites, Insecticides - Advances in Integrated Pest Management, Dr. Farzana Perveen (Ed.), ISBN: 978-953-307-780-2, InTech, Available from:

http://www.intechopen.com/books/insecticides-advances-in-integrated-pest-management/insecticide-activityof-lectins-and-secondary-metabolites

\section{INTECH}

open science | open minds

\section{InTech Europe}

University Campus STeP Ri

Slavka Krautzeka 83/A

51000 Rijeka, Croatia

Phone: +385 (51) 770447

Fax: +385 (51) 686166

www.intechopen.com

\section{InTech China}

Unit 405, Office Block, Hotel Equatorial Shanghai

No.65, Yan An Road (West), Shanghai, 200040, China

中国上海市延安西路 65 号上海国际贵都大饭店办公楼 405 单元

Phone: $+86-21-62489820$

Fax: $+86-21-62489821$ 
(C) 2012 The Author(s). Licensee IntechOpen. This is an open access article distributed under the terms of the Creative Commons Attribution 3.0 License, which permits unrestricted use, distribution, and reproduction in any medium, provided the original work is properly cited. 